\title{
The Clinical Factor
}

\author{
Giovanni A. Fava \\ Department of Psychology, University of Bologna, Bologna, Italy
}

The release of the 2009 Impact Factors by the Institute for Scientific Information has disclosed the remarkable performance of our journal. Psychotherapy and Psychosomatics is listed both in the Psychology and Psychiatry rankings. Its 2009 Impact Factor (IF) of 5.37 places the journal fifth in the psychology ranking. However, since all preceding journals are only dedicated to review articles, this means that Psychotherapy and Psychosomatics is the top journal for original investigations in psychology. In psychiatry, the journal ranks in the top 10.

The performance is the result of several factors. We should acknowledge here the perfect synchrony between Karger's editorial office and the invaluable Assistant Editors Chiara Ruini and Elena Tomba; the work of the editorial board and statistical consultants; the help of many external reviewers (listed in the appendix), who dedicated their time and efforts to assess and improve the quality of submitted manuscripts; the skills of Carlotta Belaise who prepared the press releases of the published articles; and the support of our authors and readers.

Journal editors seem to regard the IF as an objective sign of accomplishment and often dedicate to it their first editorial of the year, showing their satisfaction with small increments or minimizing decrements, as politicians do after the elections. This is what I should probably be doing. The problem is that, unlike most of my colleagues, I have actually done research on IF and citation analysis [1-5]. I cannot hide from myself that the IF is a very rough indicator, whose reliability has considerably decreased in recent years, when many journals (not ours) started listing their articles in press in Pub Med. Since the system counting citations cannot discriminate the type of articles and whether the citation refers to a published paper or one in press, a fair and appropriate comparison of journals is impossible.

For a clinical journal, however, there is something more important than the IF. It is what I would define as the Clinical Factor (CF), the degree and extent to which a journal provides information to the clinician that may improve his/her practice. Citation analysis can do very little for identifying the CF. Richard Balon, in a forthcoming issue of the journal, will try to select the papers that were published last year in psychiatric journals and that he subjectively perceived as having high CF. The CF is what we are pursuing the most. I am fully aware that by doing this I am swimming against the current scientific tide. In medicine in general, and in psychiatry in particular, there has been a progressive disappearance of papers with CF [6]. Psychiatrists are constantly reminded that genetics and neurosciences are going to transform and improve their practice. Biomarkers are considered to be the stairway to such a shift [7] and leading journals, such as the American Journal of Psychiatry and the Archives of General Psychiatry, are pursuing this perspective. Psychiatrists may share this optimism and wait for this event. Nothing has really come in the past 2 decades,

\section{KARGER}

Fax +41613061234 E-Mail karger@karger.ch www.karger.com
(C) 2010 S. Karger AG, Basel

0033-3190/11/0801-0001\$38.00/0

Accessible online at:

www.karger.com/pps
G.A. Fava, MD

Department of Psychology, University of Bologna

Viale Berti Pichat 5

IT-40127 Bologna, (Italy)

Tel. +39 051209 1339, Fax +39 051243 086, E-Mail giovanniandrea.fava@ unibo.it 
as exemplified by the field of psychiatric genetics [8] or the epidemic of research on dexamethasone suppression tests in the 1980s and1990s, but we may be really close.

An increasing number of researchers have no familiarity with the clinical process and their research indeed reflects their fears. In the meanwhile, pharmaceutical medicine is taking full advantage of the clinical vacuum, providing direction with massive doses of propaganda [9]. Psychiatrists, however, may also realize that substantial advances have taken place in clinical assessment and treatment, even though, as with the truly important news in the newspapers, they may pass unnoticed. A different clinical psychiatry is available [10] and can be practiced now.
Our journal will continue to pursue the CF. If the IF comes along, fine. Otherwise, we will not be particularly concerned. We have more important things to do: to encourage new assessment and treatment strategies in mood and anxiety disorders, where standard approaches are largely unsatisfactory; to support clinimetric instruments that may allow a better integration of psychosocial factors in clinical medicine; to unravel the essential ingredients of the psychotherapeutic process; to provide a forum for innovative thinking at the interface between behavioral and medical sciences, and to host contributions that special interest groups would not allow to appear in other journals.

\section{Appendix}

The following experts have supplemented the editorial board by reviewing the manuscripts submitted to Psychotherapy and Psychosomatics during 2010 and are gratefully acknowledged. Both external referees and editorial board members have disclosed potential conflicts of interests. The Editor-in-Chief and the Assistant Editors have no conflict of interests to declare for 2010

G. Abbate-Daga (Turin, Italy)

E. Albieri (Bologna, Italy)

K. Andreasson (Hillerød, Denmark)

B.B. Arnetz (Detroit, Mich., USA)

J.P. Barber (Philadelphia, Pa., USA)

A. Barbosa (Lisboa, Portugal)

C. Barrowclough (Manchester, UK)

A. Bartak (Amsterdam, The Netherlands)

J. Bauer (Freiburg, Germany)

H. Baumeister (Freiburg, Germany)

C. Belaise (Bologna, Italy)

S. Bellingrath (Bremen, Germany)

R.H. Belmaker (Beersheva, Israel)

M. Berk (Melbourne, Australia)

M.E. Beutel (Mainz, Germany)

E.H. Bos (Groningen, The Netherlands)

E. Bui (Toulouse, France)

G.V. Caprara (Rome, Italy)

R. Carney (St. Louis, Mo., USA)

Y. Chida (London, UK)

M. Chiesa (Richmond, UK)

D. Cohen (Paris, France)

F. Colom (Barcelona, Spain)

F. Cosci (Florence, Italy)

J.A. Cottraux (Lyon, France)

J.C. Coyne (Philadelphia, Pa., USA)

C. Cusin (Boston, Mass., USA)

M. Davis (Phoenix, Ariz., USA)

M. De Bolle (Ghent, Belgium)

A. delle Fave (Milan, Italy)

J. Dirmaier (Hamburg, Germany)

S.J. Eisendrath (San Francisco, Calif., USA)

R.S. El-Mallakh (Louisville, Ky., USA)
A. Farabaugh (Boston, Mass., USA)

E. Ferguson (Nottingham, UK)

K. Fritzsche (Freiburg, Germany)

S. Galderisi (Napoli, Italy)

S. Gostoli (Bologna, Italy)

H.J. Grabe (Stralsund, Germany)

C. Grilo (New Haven, Conn., USA)

P. Grossman (Basel, Switzerland)

J. Guidi (Bologna, Italy)

M. Hartmann (Heidelberg, Germany)

D. Healy (Bangor, UK)

M. Heins (Nijmegen, The Netherlands)

P. Hoen (Groningen, The Netherlands)

P. Høglend (Oslo, Norway)

J. Hoyer (Dresden, Germany)

R.B. Jarrett (Dallas, Tex., USA)

E. Joosten (Nijmegen, The Netherlands)

H. Knoop (Nijmegen, The Netherlands)

S. Krimsky (Boston, Mass., USA)

C. Lai (Rome, Italy)

D. Lam (Hull, UK)

F. Lamers (Amsterdam, The Netherlands)

J. Lancee (Utrecht, The Netherlands)

F. Leichsenring (Giessen, Germany)

C. Lemogne (Paris, France)

P. Leombruni (Turin, Italy)

S. Lilienfeld (Atlanta, Ga., USA)

M. Linden (Teltow/Berlin, Germany)

M.M. Linehan (Seattle, Wash., USA)

S. Linke (San Diego, Calif., USA)

A.K. MacLeod (London, UK)

A. Maercker (Zurich, Switzerland)

G. Maina (Torino, Italy)
G. Majani (Montescano, Italy)

C. Marchesi (Parma, Italy)

Y. Matsuoka (Tokyo, Japan)

A.K. Mattila (Tampere, Finland)

A. Moreira-Almeda (Durham, N.C., USA)

R. Mota Cardosa (Porto, Portugal)

S. Munsch (Basel, Switzerland)

A. Nakagawa (Tokyo, Japan)

U. Nater (Atlanta, Ga., USA)

N. Navarrete (Granada, Spain)

A.A. Nierenberg (Boston, Mass., USA)

E. Offidani (Bologna, Italy)

A. Ogliari (Milan, Italy)

J.S. Ogrodniczuk (Vancouver, Canada)

J. Ormel (Maastricht, The Netherlands)

G.I. Papakostas (Boston, Mass., USA)

M. Pasquini (Rome, Italy)

P. Pasquini (Rome, Italy)

S.B. Patten (Calgary, Canada)

R. Penadés (Barcelona, Spain)

R.H. Perlis (Boston, Mass., USA)

H. Pope (Belmont, Mass., USA)

V. Ricca (Florence, Italy)

S.E. Romans (Toronto, Canada)

B.R. Rutherford (New York, N.Y., USA)

E. Sanavio (Padua, Italy)

M. Schredl (Mannheim, Germany)

K. Schruers (Maastricht, The Netherlands)

I.E. Schulte (Bremen, Germany)

L. Sirri (Bologna, Italy)

N. Sonino (Padua, Italy)

L. Staccini (Bologna, Italy)

D.E. Stewart (Toronto, Canada) 
J. Svaldi (Freiburg, Germany)

L. Sylvia (Boston, Mass., USA)

G. Tabibnia (Pittsburgh, Pa., USA)

G.J. Taylor (Toronto, Canada)

R.A. Topciu (Rochester, N.Y., USA)

E. Tossani (Bologna, Italy)

A. Troisi (Rome, Italy)
C.M. van der Feltz-Cornelis (Utrecht, The Netherlands)

B. van Houdenhove (Leuven, Belgium)

D. Visani (Bologna, Italy)

J. Vittengl (Kirksville, Mo., USA)

H. Walach (Northampton, UK)

F. Wilhelm (Basel, Switzerland)
M. Witthoeft (Mannheim, Germany)

A. Wittmann (Vienna, Austria)

J. Wright (Louisville, Ky., USA)

S. Zipfel (Tübingen, Germany)

H. Znoj (Bern, Switzerland)

D. Zolnierczyk-Zreda (Warsaw, Poland)

\section{References}

1 Fava GA, Ottolini F: Impact factors versus actual citations. Psychother Psychosom 2000;69:285-286.

-2 Fava GA, Breno E, Guardabasso V, Stefanelli M: Encouraging academic competition in Europe. Science 2002;298:1715-1716.

-3 Fava GA, Guidi J, Sonino N: How citation analysis can monitor the progress of research in clinical medicine. Psychother Psychosom 2004;73:331-333.

4 Fava GA, Ottolini F: International trends in psychiatric research: a citation analysis. Curr Opin Psychiatry 2004;17:283-287.
5 Fava GA, Montanari A: National trends of research in neuroscience. Eur Neuropsychopharmacol 1998;8:349-352.

6 Fava GA: The intellectual crisis of psychiatric research. Psychother Psychosom 2006;75 202-208.

7 Insel T, Cuthbert B, Gavery M, Heinssen R Pine DS, Quinn K, Sanislow C, Wang P: Research Domain Criteria (RDoC): toward a new classification framework for research on mental disorders. Am J Psychiatry 2010;167: 748-751.
8 Risch N, Herrell R, Lehner T, Liang KY, Eaves L, Hoh J, Griem A, Kovacs M, Ott J, Merikangas KR: Interaction between the serotonin transporter gene (5-HTTLPR), stressful life events, and risk of depression: a meta-analysis. JAMA 2009;301:2462-2471.

$\checkmark 9$ Fava GA: Unmasking special interest groups: the key to addressing conflict of interest in medicine. Psychother Psychosom 2010;79: 203-207.

10 Fava GA, Sonino N: Psychosomatic assessment. Psychother Psychosom 2009;78:333341. 